\title{
Sustainable development of organic farming in Bulgaria - state and opportunities
}

\author{
Roumen OTOUZBIROV, Todorka ATANASOVA, Iskra NENCHEVA \\ Trakia University, Bulgaria
}

\begin{abstract}
Aim: In recent years, Bulgarian organic agriculture is one of the sectors that is developing rapidly despite of the overall stagnation in Bulgarian agriculture and is continuously growing in farming areas as well as in number of farmers. This development is related to the suitable conditions for its adoption in our country - ecologically preserved areas; awareness and willingness of consumers to eat healthy; the realization of the benefits to the environment and rural areas; institutional support for organic farming and the good perception of organic products on international markets. The aim is to examine the condition and opportunities for development of sustainable organic farming in Bulgaria.
\end{abstract}

Design/Research methods: The methods used to complete the tasks are systematic and comparative analysis, an estimated constructive method; method of statistical groupings, inductive and deductive methods of forming generalizations.

Conclusions/findings: Organic farming combines the best environmental practices, biodiversity heightening, nature conservation and high production standards. At the same time, it provides public goods in terms of rural development and responds to specific consumer demand for clean and healthy products.

Originality/value of the article: Organic production is an international, European and national priority. Organic farming plays an important part in the Common agricultural policy of EU for the 2014-2020 period, as well as for Bulgarian agricultural policy as a tool in regards to the sustainable management of natural resources, the preservation of food quality and safety and the humane farming means.

Keywords: agriculture, organic farming, agricultural policy

JEL: Q13, Q18, Q57

Correspondence address: Roumen Otouzbirov, Trakia University, Bulgaria. E-mail: otuzbirov_r@abv.bg Received: 03.10.2018, Revised: 21.12.2018, Revised: 28.02.2019, Accepted: 08.04.2019 doi: http://dx.doi.org/10.29015/cerem.747 


\section{Introduction}

In recent years, Bulgarian organic agriculture is one of the sectors that is developing rapidly despite of the overall stagnation in Bulgarian agriculture and is continuously growing in farming areas as well as in number of farmers. This development is related to the suitable conditions for its adoption in our country ecologically preserved areas; awareness and willingness of consumers to eat healthy; the realization of the benefits to the environment and rural areas; institutional support for organic farming and the good perception of organic products on international markets (Kostadinova et al. 2016).

According to Mitova (2018), in about half of the EU-28 countries, the transitional organic farming (OF) areas in the past three years are between 10 and $30 \%$ of all areas with OF. In Bulgaria, they are between 70 and $82 \%$ (the highest percentage in the EU-28). The share of the areas under transition to the OF is an indicator of the growth potential of the sector over the next few years and a can lead to a significant increase of organic products of Bulgarian origin in the domestic and international markets.

The purpose of this study is to examine the condition and opportunities for development of sustainable organic farming in Bulgaria. To achieve this objective the following tasks have to be completed: to analyze the state of organic farming in Bulgaria; to reveal opportunities for sustainable organic farming; to identify problems and summarize recommendations for the development of Bulgarian organic farming. The methods used to complete the tasks are systematic and comparative analysis, an estimated constructive method; method of statistical groupings, inductive and deductive methods of forming generalizations.

\section{Methodology}

The methods used to achieve the goal and solve the tasks are analysis and synthesis, mapping method, axiomatic method, a structural-functional approach, and statistical-mathematical methods. 
For the purposes of this study we will analyze the production potential of Bulgarian organic agriculture at individual product level. Production potential is evaluated initially on the basis of annual production, which represents the ability of the regions to produce (Lafay 1992) some organic products.

The second major factor that we will analyze and is involved in formation of the regional production potential is represented by the number of employees by age in the farming sector. In its economic essence, it is an important part in the process of formation and development of the production capacity of organic farming (Otuzbirov et al. 2012).

\section{State and opportunities of organic farming in Bulgaria}

The European market for organic products for the period 2000 to date has grown about 5 times, whereas the area under organic farming in the EU has grown about 2 times over the same period. With the launch of the new Rural Development Program (RDP) 2014-2020 (2014), the expectations for the development of organic farming in Bulgaria are increasing, as the EU funding for the cultivation of bio-products has increased 5 times (in the previous RDP 33 million euros were planned and 152 million euros are planned in the new one). For the first time, funding for organic livestock farming is also envisaged, measures such as pastoralism (seasonal grazing), conservation of endangered local breeds and other activities are also under way.

The financial value of institutional support for organic farming in Bulgaria is defined in Ordinance No. 4 (2015) of the Ministry of Agriculture and Food (MAF). The level of support in the transition period is higher than the post-transition period, due to the increased costs of producers in transforming their activities from traditional to organic farming. In the first year of operation of the Ordinance, 2,116 applications for assistance were approved and BGN 28,119,231 were disbursed, $75 \%$ of which were financed by the EU funds and $25 \%$ of the national budget. An applicant may be assisted at the same time to carry out activities in more than one direction for the period of application of the Organic Farming measure, the 
maximum amount of this support being for annual crops - EUR 600 / ha; for specialized perennial crops - 900 EUR / ha, and for other land use - 450 EUR / ha. In the latter category, breeders are most often included, combining support for pasture maintenance in the control system and the livestock units they look after using the respective pastures. This dualistic support scheme allows producers to obtain higher levels of institutional support needed to meet the increased cost of doing business (Aleksiev 2017). Biological activities are performed for a period of 5 years, with area payments covering additional costs and lost income as a result of organic management.

According to data from the Agricultural Reports of MAF (2017), by the end of 2016 the total number of biological operators registered in MAF was $7262-1089$ more than the previous year and over 20 times more compared to 2007 (Table 1). Of these, 6961 were producers, 3 aquaculture producers, 177 organic processors and 121 traders (importers, exporters, wholesalers and retailers). In 2016, the number of operators in a control system for organic production represents $7.4 \%$ of the total number of registered agricultural producers under Ordinance No. 3 of 1999 for establishing and maintaining a register of farmers in Bulgaria. Over the same period, the areas registered in the control system have increased 10 fold.

Between 2011 and 2016, both the number of organic animals in the country (Table 2) and the areas in the control system increased rapidly. The most pronounced is the increase in the number of bee colonies, where more than $30 \%$ are farmed in an organic way at the end of the period.

Table 1. Number of operators and areas in organic production in Bulgaria

\begin{tabular}{|c|c|c|}
\hline Year & $\begin{array}{c}\text { 1. Number of operators with } \\
\text { organic production }\end{array}$ & $\begin{array}{c}\text { 2. All areas in the control } \\
\text { system (ha) }\end{array}$ \\
\hline $\mathbf{2 0 0 7}$ & 339 & 15224 \\
\hline $\mathbf{2 0 0 8}$ & 311 & 16662 \\
\hline $\mathbf{2 0 0 9}$ & 476 & 11789 \\
\hline $\mathbf{2 0 1 0}$ & 820 & 25647 \\
\hline $\mathbf{2 0 1 1}$ & 1054 & 26662 \\
\hline $\mathbf{2 0 1 2}$ & 2016 & 40378 \\
\hline $\mathbf{2 0 1 3}$ & 3123 & 58107 \\
\hline $\mathbf{2 0 1 4}$ & 4092 & 74351 \\
\hline $\mathbf{2 0 1 5}$ & 6173 & 118571 \\
\hline $\mathbf{2 0 1 6}$ & 7262 & 156348 \\
\hline
\end{tabular}

Source: Agrostatistics of MAF, Bulgaria. 
Table 2. Number of animals farmed in an organic way

\begin{tabular}{|l|c|c|c|c|c|c|}
\hline Indicators & $\mathbf{2 0 1 1}$ & $\mathbf{2 0 1 2}$ & $\mathbf{2 0 1 3}$ & $\mathbf{2 0 1 4}$ & $\mathbf{2 0 1 5}$ & $\mathbf{2 0 1 6}$ \\
\hline Cattle & 976 & 1173 & 1311 & 1622 & 4209 & 9718 \\
\hline Sheep & 6648 & 9175 & 7894 & 9029 & 18792 & 26809 \\
\hline Goats & 3397 & 2831 & 3235 & 4142 & 5381 & 8242 \\
\hline Bee colonies & 58855 & 85346 & 117360 & 106676 & 178331 & 236462 \\
\hline
\end{tabular}

Source: Eurostat.

In parallel with an increase in the number of animals farmed organically, the organic production of livestock is growing (Table 3).

Table 3. Certified organic livestock products, tones

\begin{tabular}{|l|c|c|c|c|}
\hline $\begin{array}{l}\text { Certified organic products } \\
\text { of animal origin, tons }\end{array}$ & $\mathbf{2 0 1 3}$ & $\mathbf{2 0 1 4}$ & $\mathbf{2 0 1 5}$ & $\mathbf{2 0 1 6}$ \\
\hline $\begin{array}{l}\text { Milk (raw milk, produced at } \\
\text { the farm) }\end{array}$ & 2194.4 & 2486.2 & 7346.5 & 8639 \\
\hline Cheese & 26.0 & 262.6 & 30.5 & 156 \\
\hline Cultured milk & 58.2 & 238.4 & 191.1 & 240 \\
\hline Honey and bee products & 1605.6 & 1516.8 & 2159.8 & 1941 \\
\hline
\end{tabular}

Source: Eurostat.

The data unambiguously show that there is a potential for growth in the livestock breeding sector in Bulgaria. At the same time, Bulgaria is the world's leading exporter of organic oilseed rose and lavender, the world's fourth largest and the first in Europe to export herbs. The international market for organic products grows by $4-10 \%$ on a yearly basis. A minimum of $10-12 \%$ is the annual growth in consumption, according to world-wide statistics. These data is an indication that organic products will increasingly be sought on the market in the future. According to Petrova (2016), this could stabilize the income of Bulgarian farmers through the opportunity to provide healthy food products on new markets. 


\section{Sustainability of the labor force in Bulgarian organic farming}

The agricultural sector in Bulgaria shares a lot of the issues that have become characteristic for the European Union's agriculture in general. One of the most important issues is the decline of the labor recourses that are at the disposal of the sector. As shown on Figure 1 most of the people employed in Bulgarian agriculture are over 45 years old. In 2017 there are 53300 employed at the age of 35-44, 55200 at the age of 45-54, 60900 over 55 years old and just 12000 at the age of 15-24. This inability of the sector to appeal to young employees and entrepreneurs is undermining the sustainability of the sector as a whole.

When analyzing the group of young people that are currently part of the agricultural work force we concluded that most of them are focused on implementing innovative production techniques and technologies. The most commonly used innovative production opportunity is the organic farming. In 2017 over $60 \%$ of all young people employed in Bulgarian agriculture are working on organic farms and are producing mainly organic honey, wine, dairy products and cereals.

During the studied period we noted a gradual increase in the number of young people employed in Bulgarian agriculture. Although the numbers have risen since 2011, the significant drop from 2010 to 2011 was only recovered in 2017 and not fully (in 2010 there were 12100 15-24 years old employed and in 2017 there are 12 000).

We can report similar trends in all age groups besides the one from 25 to 34 years old, which have been constantly declining and just recovering since 2015 . The transition of employees between the age groups during the period should also be taken in to consideration and might have a large impact on the final conclusion for the sustainability of the sector. For the purpose of this study we are focusing our attention on the youngest group of employees, because they can form a longer term trend for the sustainable development of the sector. When analyzing the motivation of these younger employees we discovered improved willingness to implement innovations and better use of information networks. That allows us to conclude that the organic production sub-sector of Bulgarian agriculture has a better labor 
sustainability that the sector overall and can create unique opportunities for other sub-sectors as well.

Figure 1. Number of employees in Bulgarian agriculture divided by age groups (in thousands)

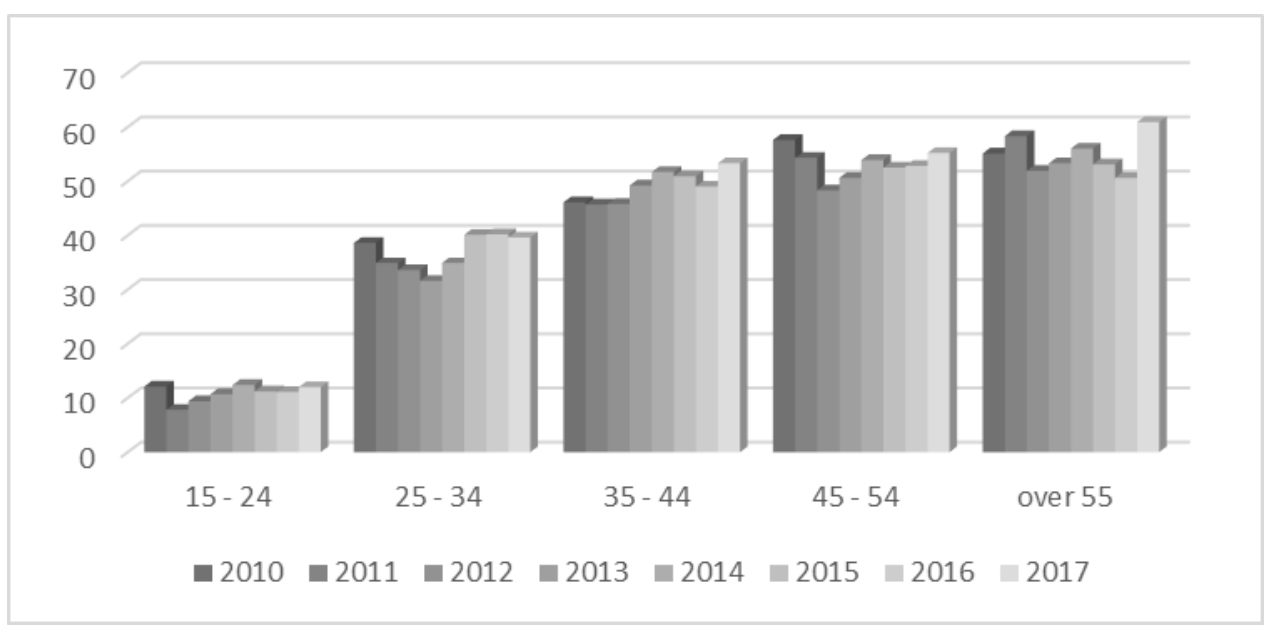

Source: National Statistical Institute of Bulgaria.

\section{Conclusions}

On the basis of the presented data and analyzes, some conclusions can be made and some of the problems of the organic agriculture in Bulgaria should be emphasized:

- In the period 2007-2017, the RDP in Bulgaria stimulates the transition towards organic production of agricultural products, leading to a significant growth in the past few years of the areas and animals in the organic production control system.

- In recent years, as a result of CAP support and market development, organic farming in Bulgaria can be defined as ascending and with good prospects.

- There is a great dependence of organic farmers on payments under the RDP - subsidies play an important role both for the cost optimization of the activity and for the maintenance of the incomes. 
- Among the key issues for the development of organic farming in Bulgaria is the lack of targeted support for the processing of primary organic production. This is essential, because the added value of this type of production is exported outside the country.

- The low numbers of young people employed in the farming sector in Bulgaria raises important concerns about the long term sustainability of the sector and its production potential. Young people find the organic farming more appealing and thus tend to choose employment in such farms when given the option, but the low number of farms forms a limited labor market for young farmers in the rural areas of the country.

Organic farming combines the best environmental practices, biodiversity heightening, nature conservation and high production standards. At the same time, it provides public goods in terms of rural development and responds to specific consumer demand for clean and healthy products. This determines the need to invest optimal efforts for the sustainable development of organic farming in Bulgaria.

The younger organic farmers in Bulgaria show the highest willingness to implement innovations and better use of information networks and allows us to conclude that the organic production sub-sector in Bulgaria has a better labor sustainability that the agricultural sector overall and can create unique opportunities for other sub-sectors as well.

\section{References}

Alexiev G., Stankov K. (2017), Influence of the institutional support on the production potential of the Bulgarian organic livestock breeding, in: Proceedings from the Scientific and Practical Conference „Agribusiness and Rural Areas - Economy, Innovation and Growth”, Varna, pp. 173-179.

Eurostat Database, http://ec.europa.eu/eurostat.

Kostadinova N., Aleksiev G., Stankov K. (2016), State and trends in organic agriculture in Bulgaria, Management and Sustainable Development, Sofia University, Sofia, pp. 78-84.

Kostadinova P., Popov V. (2012), Basic principles and methods of organic agriculture, „New Knowledge", vol. 1 no. 3, pp. 58-65.

Kristeva I. (2014), State and trends for the development of organic production in Bulgaria for the period 2006-2012. Reports from the Jubilee Conference „The National Agrarian Sector - Element of the European Agricultural Regions in the Europe 2020 Strategy", Tsenov, Svishtov, pp.179-184. 


\section{SUSTAINABLE DEVELOPMENT OF ORGANIC FARMING IN BULGARIA}

Ministry of Agriculture and Food of the Republic of Bulgaria (2013), Ordinance No. 1 on the application of the organic production rules, MAF, Sofia.

Ministry of Agriculture and Food of the Republic of Bulgaria (2014), The Rural Development Program 2014-2020, MAF, Sofia.

Ministry of Agriculture and Food of the Republic of Bulgaria (2015), Ordinance №4 for the implementation of Measure 11 „Organic farming” of the RDP for the period 2014-2020, MAF, Sofia.

Ministry of Agriculture and Food of the Republic of Bulgaria (2017), Annual report on the situation $\begin{array}{lll}\text { and development } & \text { of } \\ \text { http://www mzh government.bo/MZH/Libraries/Actual2/Annual report }\end{array}$

agriculture, http://www.mzh.government.bg/MZH/Libraries/Actual2/Annual_report_2017_EN.sflb.ashx [31.05.2019].

Mitova D. (2018), Organic farming in Bulgaria in the period 2007-2016. Sectoral analyzes in agriculture, project ХТАИ №144.2, SAA-EIA, Sofia, pp. 53-60.

Petrova N. (2017), Sustainable management of land resources and organic farming, „Trakya Journal of Sciences", vol. 15 suppl. 1, pp. 177-181. 